\title{
Influence of the Welding Process on the Martensitic and Dual Phase High Strength Steels
}

Petr Hanus, Eva Schmidová

Jan Perner Transport Faculty, University of Pardubice, Studentská 95, 532 10, Pardubice, Czech Republic, petr.hanus@upce.cz

The subject of the study are martensitic 22MnB5 steel and dual phase steel with the ferrite-martensitic structure, which are used in the automotive industry. The main purpose of the performed analyses is a study of strength differences in heat affected zones of the spot welding. For the needs of the strength decrease assessment, the critical layer of the heat affected area was experimentally simulated by different thermal influence procedures. The aim of the work is to determine the most suitable methodology for evaluating the local changes of the elastic-plastic material response. The yield strength and the deformation hardening are required constructions of safety carbody parts.

Keywords: Martensitic steel, dual phase steel, heat affected zones, yield strength, weld-joint fractures, indentation

\section{References}

[1] TICHÝ, J. (2006). Svařování v automobilovém průmyslu - 2. část. Časopis Svět svaru, Ostrava, 2006, s. 14-15.

[2] KARBASIAN, H., TEKKAYA, A. E. (2010). A review on hot stamping. Journal of Materials Processing Technology 210, 2010, 2103-2118.

[3] SAHUL, M., TURŇA, M., ŠUGÁROVÁ, J., SAHUL, M. (2013). Influence of Laser Welding Aluminium Alloy on Mechanical Properties of Welded Joints. Manufacturing Technology Journal [online]. Usti nad Labem, 2013, 2013(4), 5 [cit. 2016-04-12]. ISSN 1213-2489.

[4] SONG, R., DAI, Q. (2013). Dynamic Deformation Behavior of Dual Phase Ferritic-Martensitic Steel at Strain Rates From 10-4 to 2000 s-1, INTERNATIONAL, 2013.

[5] SVOBODA, M., SOUKUP, J. (2013). Dynamic Measurement of Four-Axle Railway Wagon. Manufacturing Technology Journal [online]. Usti nad Labem, 2013, 2013(4), 7 [cit. 2016-04-12]. ISSN 1213-2489.

[6] SCHMIDOVÁ, E., HANUS, P. (2013). Problems of Spot Welding of Al-Si Coated Martensitic Low Alloyed Steels, 30th Intermational Colloquium on Advanced Manufacturing and Repairing Technologies in Vehicle Industry, Visegrád, Hungary, 22-24 May 2013, ISBN 978-963-313-079-7.

[7] PODREZ-RADZISZEWSKA, M. (2011). Weldability problems of the technical AW7020 alloy. Weldability problems of the technical AW7020 alloy [online]. Usti nad Labem, 2011, (11), 7 [cit. 2016-04-12]. ISSN 1213-2489.

[8] KOŇÁR, R., MIČIAN M. (2014). Non-destructive Testing of Welds in Gas Pipelines Repairs with Phased Array Ultrasonic Technique. Weldability problems of the technical AW7020 alloy [online]. Usti nad Labem, 2014, 2014(1), 6 [cit. 2016-04-12]. ISSN 1213-2489.

[9] BOWMAN, K. J. (2004). Mechanical behavior of materials. Hoboken, NJ: John Wiley, 2004, xi, 334 p. ISBN 0471241989. 